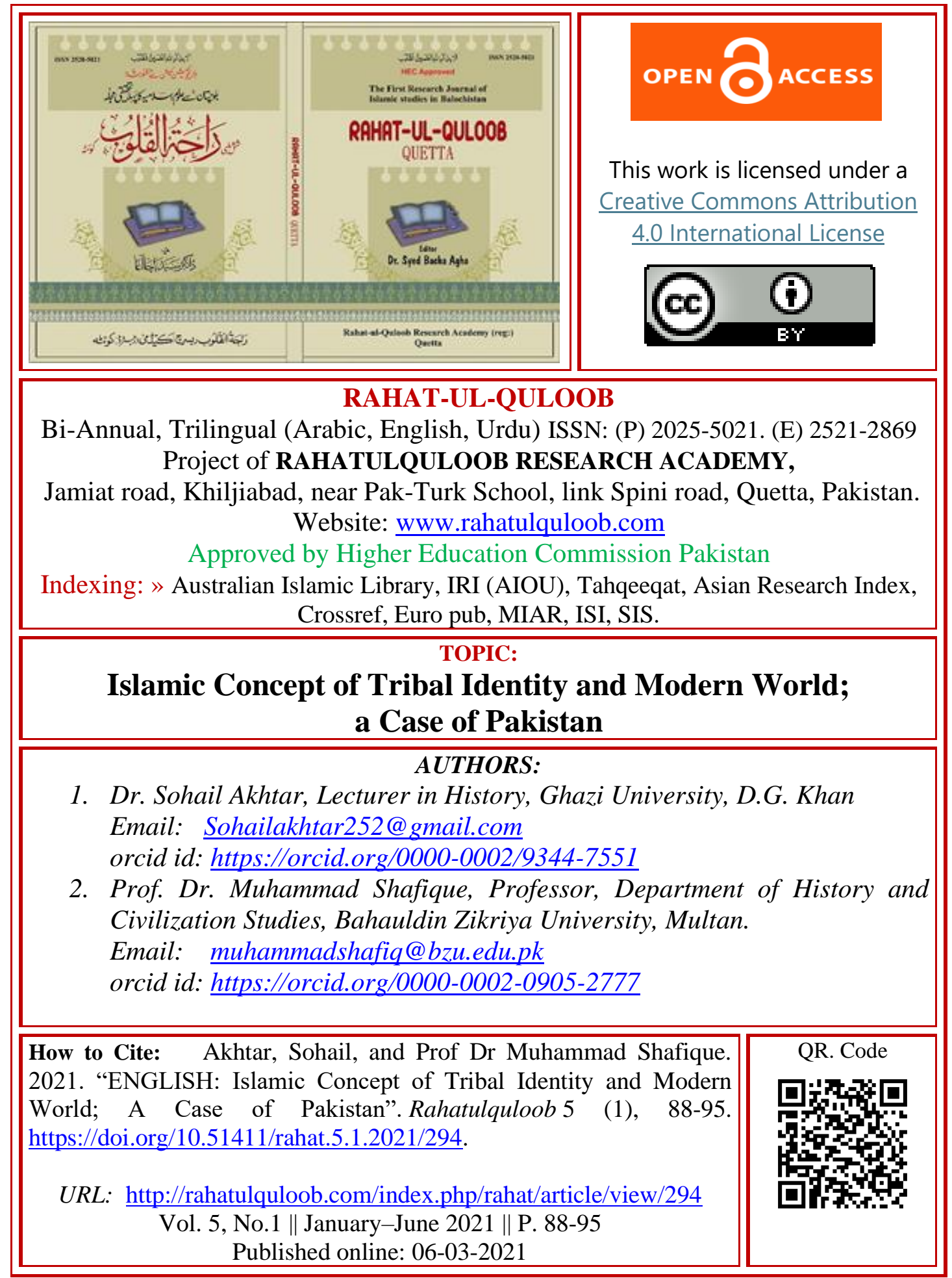




\title{
Islamic Concept of Tribal Identity and Modern World; A Case of Pakistan
}

\section{ABSTRACT:}

\author{
${ }^{1}$ Sohail Akhtar, ${ }^{2}$ Muhammad Shafique
}

Islam is a universal religion and it educated his followers that they all are equal as human being because no one is superior on the basis of color, creed, caste or blood. They all are the son of Adam and that's why the standard of superiority is only based on piety. Before the dispensation of Islam, the Arabs were divided in different tribes and the used their genealogical position and felt pride on it. Every tribe was famous due to tribal nobility and tribal strength considered as their political power. All the tribes used sword to solve the political disputes and wanted to set their tribal supremacy. The battle of Bassos and Fujar are famous for tribal supremacy. But Islam changed this concept and turned them into civilized nation. Islam declared that tribe is not factor of supremacy or superiority rather than identity of the people. This paper highlights the role of tribes as a factor of identity under the light of Islam and modern world especially when there is a concept of authoritarian democracy.

Keywords: Tribes, Islam, Identity, World, Politics.

\section{Introduction}

In Islam, tribes are considered as the source of identity not superiority. In Arab there were different tribes as Banu Hashim, Banu Umiah, Banu Adi, Banu Bakar, Banu Saqeef, Banu Khiza, Banu Qareza, Banu Nuzair. ${ }^{1}$ Even now days in the modern phenomenon of the world politics the concept of tribe or ethnic groups is only to achieve the goal of the rights or their representation in the state with the existing political system. In the world there are many groups and they tried to acquire the political and economic advantage with their strength. The world politics especially after the World War-II persuaded the racial, lingual and ethnic groups to cash their ethno-national position for their identity due to democracy.

\section{Review of Literature}

Literature has important role in research and the most concerned literature for this paper has used. The primary \& secondary sources as the Holy Quran and historical books i.e., Tabqat, Tareekh-e-Masoodi, Muqadima Ibne Khaloon and contemporary material has been used. While the historic method has been used in this research paper.

\section{Discussion}

The word tribe is basically used for a social group which belong to same race or the people who same genealogical tree and they have similar features and characteristics of life is called tribe. ${ }^{2}$ Before the advent of Islam the humanity was divided in communities and society was facing stratification on the basis of strength and power. There was a system of slavery and was a sound business of human purchase and sale. Slaves were considered the lowest standard people of the society and there was a rule 
of might is right. But Islam abolished all the non-human traditions and custom from the society due to its universality. ${ }^{3}$

As compare to other nations and religions, Islam which is universal religion explains the status of the individual. It emphasis on piety rather than caste, color and creed as the Holy Quran Says in surah Hujrat;

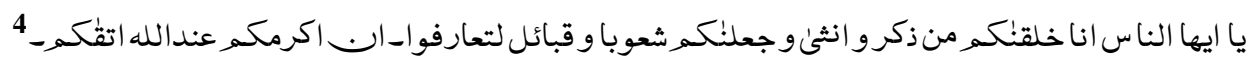

"O, People you all were created from a man and a woman and we created your castes and tribes, So that you might recognized but a superior among you is one who adopt piety"

This is a clear message that your castes and your tribes are your repute and you can recognize through this and mentioned that all are equal and created same as Quran said,

$$
\text { الذى خلقكمى من نفس واحدة_ }
$$

He it is who, hath produced you from a single being

While the Prophet (PBUH) said about it, the whole creature that they are as;

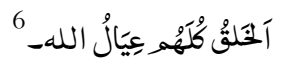

For equality Islam emphasized that people should not adopt pride and arrogance. As they used it in various time before Islam that the tribe is superior.

In his last address at Arfat, the Prophet said,

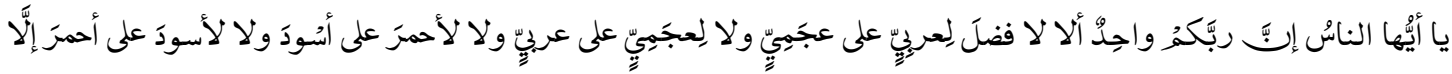

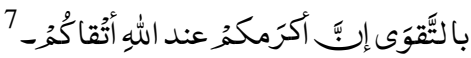

"O" people listen to me carefully, you all are the followers of Allah and there is no priority of any Arab to a non-Arab or rich on poor or any white on black except piety. In Islam the concept of nation is related to Religion and it creates harmony among the followers and they are called Ummah as Iqbal said;

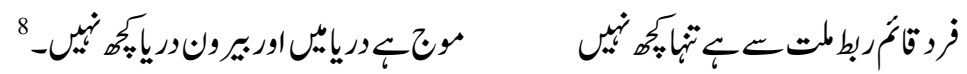

Before the advent of Islam all the Arabia was divided in tribal structure and every tribe was sovereign and autonomous is in its territory. Every tribe was completely independent in its jurisdiction and were not under any external sovereignty. These tribes fought many times for their tribal supremacy. Tribal revenge took many years and it considered necessary for the tribes in this regard many battles continued for forty years. ${ }^{9}$

The Arabs considered savages before embracing Islam they lived tribal life and robbery was the profession of these tribes while robbery considered as pride. Even after the dispensation of Islam these tribes did not give up their tribal identity. The Jews tribe of Madina also expressed their tribal nobility. While the tribal conflict between Bani Hashim and Bani Ummiad and Abbasid is also a Part of Islamic History. ${ }^{10}$ Pakistan is a plural state and it established on Islamic ideology. The founding base was Kalima 
but the different tribes are inhabiting in this state are also want their identity to gain their socio-political and economic rights under the constitution of Islamic republic of Pakistan. Different ethno-nationalist movements are the result of their political awareness and it is also considering their political exploitation. ${ }^{11}$ Allama Iqbal always tried to construct the Muslim identity as ،

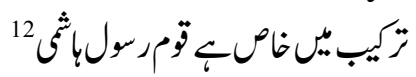

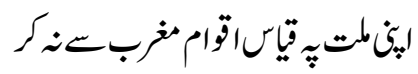

Although the majority of people is Muslim and there is no conflict but the economic sources motivates the marginalized people of remote area to use this tool of ethnicity so that tribal card may be fruitful for them. In the context of identity, the changing phenomena of the world all the people are struggling for their political rights after World War-II, therefore the marginalized groups especially used the ethnic card to achieve their socio-political and economic rights in plural states. The ethno nationalist and racial movements provided oxygen to all deprived groups and they used their identity in politics to gain a share in power mechanism. In this context ethnicity became a popular mode of politics in the plural societies. The study of identity is an important phenomenon of modern era and different scholars have explained the term. Pakistan is a country of multi-ethnic and multi-lingual region since centuries. The Muslim of Subcontinent was not ethnically homogenous and loyalties of the people were ethnically motivated. Ethnic based movements have been dominant since the colonial era. The decentralized future frame work presented by All India Muslim League was more appealing to these provinces and regions as compare to All Indian National Congress. All he Muslims of India united on their religious identity against powerful Hindus. But after the creation of Pakistan, the dilemma of ethnic identity rose and could not be resolved.

\section{The Issue of Identity and Pakistan and Politics}

The issue of identity appeared in the modern world as a factor of political power on basis of their tribal strength, although Pakistan is an important Muslim Country of the world but the role tribal politics is also considered significant in the political environment. The idea of racial supremacy is always involving in human nature as in the ancient time people felt pride on their genealogical background. The term of identity is also existing in modern world and first it seems to be in the Oxford Dictionary in 1972. ${ }^{13}$ As Mazari Stated, that, "ethnicity is cultural and linguistic symbols at a basic level and which provides internal cohesion and differentiate an ethnic group from other groups. According to her, ethnicity is also a type of social organization to class formation". ${ }^{14}$ The concept of ethnicity is not limited it is very vast and two major schools of thoughts explained it in their own as the Primordialist and instrumentalist Whale The Geertz Primordialist defines ethnicity "the cultural givens assumed blood ties, race, language, region, religion and custom as the heart of the ethnic matter". ${ }^{15}$ Instrumentalists focus upon competition and interaction their stress is on the situational and circumstantial nature of ethnic solidarity. They consider ethnicity as a weapon in the pursuit of collective advantages. ${ }^{16}$ 
"Ethnic group is a collection of people who share some patterns of normative behavior and form a part of a larger population, interacting with people from other ethnic groups within the framework of a social system. For Cohen, one of the characteristics of a people so addressed as an ethnic group is the "sharing of normative behavior". This normative behavior is a distinct behavior which distinguished one group of people from others and it include kingship, marriage, friendship, festival, rituals and other similar ceremonial activities. Normative behavior can also be coupled to the continuous interactions with another distinguished group especially within the same Nation-State. Therefore, ethnicity can be seen as interaction between culturally distinct groups operating within a common social context. ${ }^{17}$

During Ayub regime East Pakistan mostly felt exploitation, deprivation and marginalization because they said west wing is not providing the enough share of their economic sources. People of Bengal were demanding separate provinces as autonomous unit with separate governor. It was the first ethnic crisis in Bengal during Ayub but he did not take any notice of such voice. ${ }^{18}$

Table Showing Per Capita GDP of East and West Pakistan. ${ }^{19}$

\begin{tabular}{|c|c|c|c|c|}
\hline Year & $\begin{array}{c}\text { Per capita GDP } \\
\text { East }\end{array}$ & $\begin{array}{c}\text { Per capita GDP } \\
\text { West }\end{array}$ & $\begin{array}{c}\text { East- West Disparity } \\
\text { Ratio }\end{array}$ & $\begin{array}{c}\text { Disparity } \\
\text { index }\end{array}$ \\
\hline 1959 & 269 & 355 & 1.32 & 100 \\
\hline 1960 & 277 & 363 & 1.31 & 97 \\
\hline 1961 & 286 & 376 & 1.31 & 97 \\
\hline 1962 & 277 & 397 & 1.42 & 131 \\
\hline 1963 & 299 & 408 & 1.36 & 113 \\
\hline 1964 & 293 & 426 & 1.45 & 141 \\
\hline 1965 & 295 & 427 & 1.45 & 141 \\
\hline 1966 & 290 & 448 & 1.54 & 169 \\
\hline 1967 & 307 & 468 & 1.52 & 163 \\
\hline 1968 & 312 & 490 & 1.57 & 178 \\
\hline 1969 & 314 & 504 & 1.61 & 191 \\
\hline
\end{tabular}

In the election 1970 when Awami League won the election and political situation became worst no solid attempt were made and the identity issue remained serious and important one and Bengali want to get the power at any cost after winning election. ${ }^{20}$ Ayub Khan accepted his failure and handed over the power to Chief of Army Staff Agha Muhammad Yahaya Khan on $25^{\text {th }}$ March 1969. ${ }^{21}$ Yahaya Khan issued legal framework order in March 1970 to hold the election and promised to grant provincial autonomy and the rights to the people of both parts. He decided the representation of both parts on the basis of population and election policy was adopted on basis of one man one vote. 300 general and 13 reserved seats for women were decided for National Assembly and allocation of seats for each province was as following.

Seats for Nation Assembly ${ }^{22}$ 


\begin{tabular}{|c|c|c|c|c|}
\hline \multicolumn{5}{|c|}{ Rahat-ul-Quloob / Vol.5, Issue.1 (Jan-Jun: 2021) } \\
\hline Sr.No & Description & General Seats & Women Seats & Total Seats \\
\hline 1 & East Pakistan & 162 & 07 & 169 \\
\hline 2 & Punjab & 82 & 03 & 85 \\
\hline 3 & Sindh & 27 & 01 & 28 \\
\hline 4 & NWFP & 18 & 01 & 19 \\
\hline 5 & Balochistan & 04 & 01 & 05 \\
\hline 6 & Frontier Area & 07 & 0 & 08 \\
\hline & al Seats & 300 & 13 & 313 \\
\hline
\end{tabular}

Provincial Assemblies Seats ${ }^{23}$

\begin{tabular}{|c|c|c|c|c|}
\hline Sr. No & Description & General Seats & Women Seats & Total Seats \\
\hline 1 & East Pakistan & 300 & 10 & 310 \\
\hline 2 & Punjab & 180 & 06 & 186 \\
\hline 3 & Sindh & 60 & 02 & 62 \\
\hline 4 & NWFP & 40 & 02 & 42 \\
\hline 5 & Balochistan & 20 & 01 & 21 \\
\hline
\end{tabular}

After L.F.O Bhutto started his campaign on economic issue and he promised to uplift the economic position of the people with the slogan of "Roti, Kapra Makan"While Mujeeb rose his voice for the rights and his six points became popular in East Pakistan and their impacts looked in general election. Mujeeb contested election on the basis of the rights of the East Pakistan. The general election 1970 changed the whole political condition in East Pakistan. In East Pakistan the situation was changed by Awami League and gained absolute majority under the leadership of Sheikh Mujeeb ur Rehman.

\section{Party Position in National Assembly ${ }^{24}$}

\begin{tabular}{|c|c|c|c|c|c|c|c|}
\hline $\begin{array}{c}\text { Sr. } \\
\text { No }\end{array}$ & Political Party & $\begin{array}{c}\text { East } \\
\text { Pakistan }\end{array}$ & Punjab & Sindh & NWFP & Balochistan & Total \\
\hline 01 & Awami League & 160 & 0 & 0 & 0 & 0 & 160 \\
\hline 02 & PPP & 0 & 62 & 18 & 01 & 0 & 81 \\
\hline 03 & MLQ & 0 & 01 & 01 & 07 & 0 & 09 \\
\hline 04 & CML & 0 & 07 & 0 & 0 & 0 & 07 \\
\hline 05 & J.U.I & 0 & 0 & 0 & 06 & 01 & 07 \\
\hline 06 & J.U.P & 0 & 04 & 03 & 0 & 0 & 07 \\
\hline 07 & N.A.P & 0 & 0 & 0 & 03 & 03 & 06 \\
\hline 08 & J.I & 0 & 01 & 02 & 01 & 0 & 04 \\
\hline 09 & Convention M.L & 0 & 02 & 0 & 0 & 0 & 02 \\
\hline 10 & P.D.P & 01 & 0 & 0 & 0 & 0 & 01 \\
\hline 11 & Independent & 01 & 05 & 03 & 07 & 0 & 16 \\
\hline \multicolumn{2}{|c|}{ Total Seats } & 162 & 82 & 27 & 25 & 04 & 300 \\
\hline
\end{tabular}

The election's results were totally in the favor of Awami league and Mujeeb-ur-Rahman because Awami League received absolute majority in all over the Pakistan and it swept 
the elections in East Pakistan. ${ }^{25}$ Even the country lost its national integration and in 1971, East Pakistan was separated. The downfall of Bangladesh supported other deprived groups as the Saraiki speaking people of South Punjab whose identity is not recognized started a struggle for their separate identity and the issue of ethnicity and ethnic conflict raised in Pakistan. In 1977, Zia imposed martial law in Pakistan again with $3^{\text {rd }}$ time in the history of Pakistan and during Zia Regime the state policy remained same in its spirit. Ethnic groups again demanding for their due rights especially political representation and Zia focused a new emerging identity of Urdu speaking in Sindh as Muhajir, he availed this opportunity and adopted the policy of divide and rule as his ancestors in the past. ${ }^{26}$ During the regime of Musharraf ethnic conflict rose again in Balochistan \& Karachi. The murder of Nawab Akbar Bugatti created unrest in Balochistan while in Sindh Musharraf again fully supported to MQM. In urban areas of Sindh MQM swept the election through rigging and violence which destroyed the peace of Karachi and provincial govt: has become support less. After Musharraf in PPP and PMLN time ethnic politics is considered now the important tool of victory Punjab and Sindh card was used by PPP and PMLN respectively. In Sindh MQM used Muhajir soba card and in south Punjab the voice of Saraiki Province is also in progress now a days.

\section{Conclusion}

Islam is a universal religion and with its dispensation one of its teaching was equality that all the people of this world are the son of Adam and they have no superiority among ones therefore they all will be treated on equal basis. In Arabia the tribal system was in progress and each tribe wanted to maintain its supremacy on the basis of its strength and fame. But Islam declared all equal and tribes were for their socio-political identity rather than nobility. The social concept of Al-Asbiya is found in every plural society and that's why the Islamic state faced such challenges through ages of the Islamic History. The use of ethnic identity is considered very important to gain power in the world and even in the modern world different groups use their ethnic and racial or linguistic identity. Although Islam dislikes this standard of Superiority but as an understanding power tool Islamic states are still facing this political challenge not as religious challenge. In Pakistan, the sole ambition of these ethnic groups is to protect not their identity but also gain powers. In this paper it is tried to highlight the dilemma of identity in Pakistan.The downfall of East Pakistan decreased the identity as Muslim and increased to motivate the regional identities as ethnic card especially in NWFP and Balochistan during Bhutto era. While during Zia regime MQM and Sindhi Nationalist were promoted against Peoples Party. MQM became a dominant ethnic and linguistic group of Urban Sindh especially in Karachi and Haiderabad. In South Punjab the issue of Saraiki identity has been raised, due to injustice, inequality and imbalance distribution of resources and representation as compare to upper Punjab. In the last election a group of politicians contested the election on the slogan of South Punjab as a Separate province. So, the issue of identity is a reality in Pakistan it is not a problem actually need is to address different groups. To minimize and reduce the 
negative impact of identity, it is necessary for the state to address the socio-political and economic problem at regional level and provide maximum representation to marginalized groups. The equal distribution of equal sources and avoidance to creating economic imbalance among the different ethnic by providing fiscal autonomy at basic unit level can also minimize the concerns linked with ethnic politics. It can be concluded it with that as Islam provided the equal rights to the citizens, it is necessary for the personal satisfaction of the groups that maximum participation and inclusions of the identity of groups in the political process is the key to the unity and national and religious solidarity in a multi-ethnic based Islamic state. The issue of identity is rises as problem in Pakistan when the powers of groups are not recognized by decision makers. This becomes problematic when demands and concerns of different communities are not addressed. Democracy has a capacity to solve problems which is only possible through power sharing and the continuity of rights to the people. In this context, the principles of Islamic ideology for humanity are best option for all political challenges.

\section{References}

\footnotetext{
${ }^{1}$ Muhammad Bin Saad, Tabqat, Voll.I, Nafees Academy, Karachi, 1985, P.27.

${ }^{2}$ Marcus, Society and Culture, Sage Publications, London,2001. P.163

${ }^{3}$ Al-Masoodi, Morwaj-ul-Zahab, Nafees Academy, Karachi, 1987, P.114.

${ }^{4}$ Al-Quran, Surah Hujrat 49, Verse 13.

${ }^{5}$ Al-Quran, Surah Al-Anam 06, Verse, 98.

${ }^{6}$ Al-Bahqi-

${ }^{7}$ Al-Bahqi,5137

${ }^{8}$ Allama Muhammad Iqbal, Dr., Zarb-e-Kaleem, elm-o-Irfan Publiher, Lahore, 2006, P.86.

${ }^{9}$ Solat, Sarwat, Milat-e-Islamia ki Mukhtasar Tareekh, Islamic Publications, Lahore, 1993, P.35.

${ }^{10}$ Akbar, Shah Khan, tareekh Islam, Nafees Academy, Karachi. 2005, P. 13.

${ }^{11}$ Tahir Amin, Nationalism and Internationalism in Liberalism, Marxism, and Islam, Islamabad, International Institute of Islamic Thought, 1991.

${ }^{12}$ Muhammad Iqbal, Allama, Zrb-e-Kaleem, Ilm-o-Irfan, Lahore, 2005, P.87.

${ }^{13}$ Thomas, Erikson, Ethnicity and Nationalism; Anthropological Perspective, London, Pluto Press, 2000.P.19

${ }^{14}$ Shireen M. Mazari, Ethnicity and Political Process; The Pakistani Experience, op. cit, P.2.

${ }^{15}$ G. Greetz, the Integrative Revolution; Primordial Sentiments and Civic Politics, 1967, pp. 167-188.

${ }^{16}$ Tahir Amin, op.cit. Ethno National Movements of Pakistan; Domestic and International, P. 27.

${ }^{17}$ Paul R Brass, Ethnicity and Nationalism, New Delhi, Sage Publications, 1991, pp. 18

${ }^{18}$ Rounaq Jahan, Pakistan: Failure in National Integration, New York, Colombia Uni: Press, 1972, p. 34

${ }^{19}$ Uneven Development and Ethnicity, P. 180.

${ }^{20}$ Ethnicity and Politics in Pakistan, P. 42.

${ }^{21}$ Constitutional Development in Pakistan, P. 127

${ }^{22}$ Dr. Safdar Mahmoud, Constitutional Foundations of Pakistan, PP. 623-627.

${ }^{23}$ Election's Results 1970, Election Commission of Pakistan.

${ }^{24}$ Ibid.

${ }^{25}$ Ayesha Jalal, The State of Martial Rule, Pakistan's Political Economy of Defense, Sang-e- Meel Publications, Lahore, 1999, p. 312.

${ }^{26}$ Ian Talbot, Back to Future, in Pakistan at the Millennium Karachi, Oxford Uni: Press, 2004, p.73
} 